\title{
Research of Foreign Exchange Management Legal System
}

\author{
Yang Bai \\ School of Economics Law \\ Polytechnic University \\ 399 Bin Shui West Street, Tianjin 300387, China \\ E-mail: baiy1123@163.com
}

\begin{abstract}
As the foreign exchange management mode undergoes the conversion from direct-management to indirect-management, foreign exchange and financial supervision system have being perfected by relative department. Especially in recent years, financial laws and regulations have got further regulation adjustment. However, in the whole financial law system, foreign exchange control in the whole system. So, consummating the currency law in force has become the most significance in building laws of foreign exchange.
\end{abstract}

Keywords: Foreign exchange management, Supervision limit, Legislation adjustment

\section{The outline of exchange management and legislation condition}

\subsection{The outline of exchange management}

Exchange management is also called exchange control, it is management system which takes some restrictions on transaction, lending and borrowing assignment, revenue and expenditure international balance in one country. The others goals are accumulate and contribute exchange capital according to the policy so then capital outflows can be limited and exchange speculation can be avoided, which can accelerate and promote the country economy. Exchange management, as a very important tool of macro coordination and financial activity specification, the most fundamental concept is to maintain a secure and steady financial setup from the angle of foreign exchange, promote more equitable finance and protect the interest of investor and depositor.( Peng,2003,pp.142-145).

\subsection{Legislation condition of exchange management}

Our country always institute strict exchange management regulations, under the policy of reformation and opening, laws about currency management were published in succession, which was the initial exchange management rules system in our country. The provisional regulation of exchange management is the first relatively systematic administration laws and regulations in China.

Office procedure on exchange of non-bank financial institution, specification on exchange management of bank and specification on exchange management of non-bank financial institution were published in succession from 1984, which establishes the law frame on how financial institution engage in the exchange. As exchange management enters into a deep reformation, exchange management regulation of PRC was issued by the state council in 1996. Be as currency management institutions, the people's bank of China and exchange management bureau also publish a great quantity of administrative regulations and canonical documents, which were the important part in exchange management system in country. In the end of 1996, the system got a further promotion-convertibility of current account was realized, on the basis of which exchange management regulations make it clear that the goals of currency management are keep international balance and develop the steady economy.

\section{Limitations of foreign exchange management legal system}

\subsection{Limitations of exchange rate system}

At present, the implementation of a single, managed floating exchange rate system is a reflection of the economic and financial market, with the RMB current account convertibility of the requirements. However, accession to the WTO balance of payments faced by the impact of foreign currency has been China's RMB exchange rate system is not well suited. China still maintains capital controls exchange rate of RMB exchange rate to a large extent depend on the current foreign exchange income and expenditure over the past practice of trade liberalization, trade reform would lead 
to the domestic economy and balance of payments situation facing the major Impact of inappropriate exchange rate policies will eventually lead to balance of payments crisis, a fixed exchange rate system and the rigid exchange rate peg prices are unreasonable, together with the accession to the WTO chief to cut tariffs on non-tariff barriers and the elimination of China's domestic economy And the huge balance of payments impact, We can see that both the efficient allocation of resources from the point of view or from the balance of payments situation, take a fixed exchange rate system is inappropriate, after China's accession to the WTO will face increasing capital flows, and the capital account deregulation of the trend to adapt The need for a more flexible exchange rate system, if still rigid exchange rate policy is bound to result in nominal exchange rate appreciation pressure on domestic monetary policy with the objective of the conflict between.

\subsection{Limitations of current foreign exchange control}

Review the way trade in goods, foreign exchange constraints. China's agreement to accept IMF, to trade under the exchange rate does not limit the use of foreign exchange, but the WTO has the right to operate import and export business increased to gradually open up the right to operate import and export controls, improve the current review in order to increase efficiency, improve Management means and methods, Create remittance advices from the audit into the overall review. At the same time, along with the expansion of trade in services, the purchase and payment mate, to the current foreign exchange management has posed a serious challenge, as our country's current account convertibility, trade in services under the purchase payment is not the approval of Foreign Exchange, Canada Great review of the difficulty of trade in services back to the territory of foreign exchange earnings in a timely manner a lack of effective means of supervision. In addition, with the increase in foreign relations, movement of natural persons are also growing rapidly and a large number of the foreign exchange needs of individual residents and non-resident individuals and foreign exchange management to be sound.

\subsection{Constraints of capital account foreign exchange}

\subsubsection{Imperfect rules}

Some of the business capital of the lack of appropriate supervision and regulations on the basis that no legal basis; although some of the provisions are not perfect, violations of the penal provisions are too general and simple. Either for or appointed agent, or is there is no legal basis for the "vacuum", or failure to abide by the emergence of "supervision of tolerance." The existence of a large number of our country through executive orders, regulations and inform the implementation of the regulation, supervision appears to be impetuous and blind, to implement at a loss, did not achieve the purpose and effect of the regulation.

\subsubsection{False information}

Capital account data on the basis of distortion, the main reason is that some of the foreign exchange banks operating strictly guard the pass, even false, false table, fraud, making a number of enterprises run away kit illegal trading of foreign exchange and foreign exchange violations occur from time to time. These "man-made" abnormal factors often induce foreign exchange management supervision into the "information distortion of the trap." If the foreign exchange regulatory authorities of relevant information and have not foreseen, the family property unclear, it is easy in the event of a crisis, not to take countermeasures.

\subsubsection{Backward means of monitoring, the cost is too high}

In the foreign exchange abroad, the central bank is monitoring the project set up a special authority, and then down again through the indirect management of commercial banks. However, in our country, it seems there is a foreign exchange bank worried about the psychological, foreign exchange management departments under the direct supervision can not resist the temptation to have the item, the results are often counterproductive, resulting in increasing the cost of management, supervision and access to information and efficiency do not have geometric enhance. At the same time, over supervision procedures and links, making banks and enterprises to reduce operational efficiency, not to achieve a "win-win."

\subsubsection{Encourage and participation in soft constraints}

Regulatory capital is the main objective of the regulation and control capital outflow and maintain balance of international payments, but the goals and interests of the banks do not have good coordination in the bank at the same time the interests of the pursuit of subjective and objective and not entirely outside the control objectives Line. Compared to the existing capital project management to comply with the provisions of the costs, some banks and companies more willing to obtain illegal gains, a number of individuals through deception to obtain additional income and feather one's nest. Corresponding to these violations and the punishment of individuals are generally or a symbolic point penalty shall get away. Punishment is smaller than the cost of illegal proceeds, so that the irregularities have been virtually conniving form of a check-off non-recurrence of the vicious circle of reduced incentive effects of foreign exchange regulation. 


\section{The demand of foreign exchange supervision and legislation}

\subsection{The management demand of foreign exchange administration in different period}

At first, convertible period of frequently account. In this period, the main job for exchange management are as follows: putting forth efforts to the exchange administration and transferring the work examined by Bureau of Exchange Management which within the current account in forth to the authorized bank, loosing the exchange administration to long-term capital item, and avoiding international floating capital speculating into our finance market, monitoring the finance business which interrelated to exchange, establishing check system for exchange funds circulation .The second ,the period that capital item convertible but RMB not international .On the limit of economic strength and risk precaution ability.(yang,2002,p.252). We must realize the capital item convertible. Exchange management bureau transfers to market regulation, but not related to enterprise .If the currency in one country realizes the internationalization ,the degree of regulation .If the currency in one country realizes the internationalization ,the degree of regulation difficulty will be higher .In order to establish a steady finance environment anti-speculation system of currency has been set up .

And an open capital market of RMB should be formulated to control quantity of property reserved abroad .At last, period that the internationalization and regional of RMB. This period formatted naturally as long as the economic strengthens, economic cooperation scope extends and market portion enlarges .Central Bank always cares the exchange situation in china and abroad, regulates and intervene the exchange rate ,raise investment interests of foreign exchange reserve and prevents international Money-laundering .

\subsection{Legislation need of exchange management}

First, rule-draw up procedure should be standard .In China, most drawer of exchange management rules are government functional departments-Central Bank and Exchange Management Bureau, but in front of which are obvious administrative destinations, so the rational and fair will must be influenced .In fact, administrative destination and obligation of exchange market are more but rights and interests are not enough emphasized in rules and regulations of exchange management in force. In most of times, law-drawer and law-executor are one person, which has hampered the system formation to standard the supervisor and executor .Because of strict operating rules lacked during the period of the planning,drafting and modifying as result that some regulations can not be guaranteed, and then regulation system should be arranged. Exchange management rules in force are still void of strict executive and monitoring standard. (luo, miu,2001,p.272).

For now channels to investigate the management rule have not been affirmed by the law definitely especially for some special articles are only canonical documents in practice. The documents should be implemented of exchange legal norm.

\section{The adjustment of current legal norm}

\section{1 adjustment of current account}

Further relax the standard of opening an account .It not only enlarges the open scope of native enterprise ,but also unifies the open condition of native enterprise and foreign-capital enterprise .Merging the account type-exchange settle account and special account are merged into foreign exchange account, reduces the prime cost of management and convenience the operation of enterprise .United ration management and in-used information system of exchange account management, can make the efficiency of management.

\subsection{Adjustment of capital account}

Perfect "Management Rule" is the basis of supervision and encouragement regulation. (shi,2006,p.36).

At present, supervision is carried out by plenty of administrative regulations, some mature contents among which should be up to be law at the right moment, and be steady infixed time. At the same time, legislation should be perfected. The Standardization and prevision should be promise. And, information of exchange management should be shared aiming to makeup an effective, speedy and exact information system of management.

\subsection{Adjustment of $R M B$ exchange rate and store}

Remittance is the keynote of the management. During the initial stage of socialism, stabilizing the RMB exchange rate and exchange store should be regarded as central work. At present, cash flow will be exerted only after the exchange of RMB and foreign currency. So the stabilization of RMB exchange and scale of exchange store will be influenced by exchange directly.

We had not open convertible RMB within the scope of current account. Until the end of 1996, but maintain the control of foreign exchange to the capital account. Therefore, developing foreign finance market and then developing native finance market will make the latter not lashed by the former. 


\subsection{Adjustment of foreign exchange management}

At first, the subject position of management institution should be definite. For one thing, maintenance of the market body interest ought to be strengthened. For another, bring the administrative institution of exchange management into finance supervision system. We make the jurisdiction of the exchange management institution clear. We divide the work of Central Bank form it of exchange management setup. And then we make the exchange management and finance management a unity, standard the measures of exchange management. The feature of management contents should be divided definitely and different measures should be adopted. At the same time, enforcing the law must take the principle of according to the law. All measures and procedures taken must be within the law-scope. At last, strengthen the cooperation of management departments, joining the international system of finance structure, approving the standards of finance innovation, strengthening the supervision to the market participator and reaction system against to the infection, reducing the possibility of high-rate risk accompanying the exchange business innovation and small cash becoming crisis, broadening management cooperation scope and strengthening the international harmonization, and then a fine economy environment which benefit for finance development can be established.

\section{References}

Luo, Pei Xin, Miu, Jian Wen. (2001). WTO and international financial law. Ji Lin: E-Publishing Inc. p275

Peng, Hong. (2003). Research of foreign exchange management legal system. Zhong Shan :E-Publishing Inc. pp. 142-145

Shi, Li Ya. (2006). Discuss the foreign exchange management of China and WTO. Ji Nan:E-Publishing Inc.p36

Yang, Song. (2002). Research of international law and international currency order. Bei Jing: E-Publishing Inc. p252 